\title{
Prodded retrieval from a semantic category
}

\author{
CARL P. DUNCAN \\ Northwestern University, Evanston, Illinois 60201
}

\begin{abstract}
Two hundred subjects were required to write down a specified number of names of birds. Absolute frequencies of names emitted were higher than those found by Battig and Montague (1969), but, as they also found, frequencies decreased sharply from a few high-frequency names.
\end{abstract}

In connection with the study of retrieval of low-frequency words (e.g., Duncan, 1973), it became desirable to use low-frequency members of a semantic category. Accordingly, the Battig and Montague (1969) norms were consulted. However, in many of their categories, the frequency of occurrence declines sharply after the first few high-frequency items. Consider the category of "birds." Of Battig and Montague's 442 subjects, 377 (85\%) gave "robin," the most frequent response. The fifth most frequent (eagle) was given by only $161(36 \%)$ of the subjects. The 10th most frequent (hawk) was given by 111 (25\%). About 100 different acceptable bird names (my judgment) were produced, but the great majority of them were emitted by less than $10 \%$ of the subjects. Another way of looking at Battig and Montague's data is to note that although college student subjects would almost certainly recognize most of the 100 bird names, the mean number produced was only 7.35 . Thus, many names were stored but not retricved. This raised the question: can subjects be prodded to give more of the bird names that we know are in their heads? If so, will greater production raise the frequencies of emitted names, change the rank order, increase the total number of different names emitted, etc.?

\section{METHOD}

Battig and Montague had run most of their subjects in large classroom groups. Their subjects were given $30 \mathrm{sec}$ to write members of one category, then went on to another category, for a total of 56 categories. In the present study, subjects were run in a laboratory room in groups of 5-10. They served in the study to fulfill part of the subject service requirement of the introductory psy chology course. The experimenter handed out a data sheet containing 24 blanks (two columns of 12) to each subject and said, "This sheet has 24 spaces. I want you to write down the name of a bird in each space. Each space is to have a different bird name. We know that college students know about 100 bird names, so you should be able to think of 24 . As soon as you have written a different bird name in each space, you may leave."

When subjects signed up for the experiment, they had been told that the time involved would be up to $30 \mathrm{~min}$. However, the relatively few subjects who had not left after $20 \mathrm{~min}$ were allowed to leave.

The subjects were 200 students, enrolled in introductory

The extensive help of Dr. Alan Brown is gratefully acknowledged. psychology classes at Northwestern University during the academic years 1972-73 and 1973-74. Battig and Montague's subjects were 270 students at the University of Maryland and 172 students at the University of Illinois (Champaign-Urbana), all run in 1965 .

\section{Results and Discussion}

Almost all subjects filled in all of the 24 blanks. However, as Battig and Montague also found, a few responses were "jailbird," "foobird," etc. These and occasional other chaff were not counted, but it is still not easy to determine exactly what should be considered different responses, e.g., "eagle," "bald eagle," "golden eagle." Battig and Montague recorded such responses separately. Following their procedure, it was found that Northwestern subjects produced a mean of 23.1 responses and a total of about 140 different bird names.

Table 1 shows the rank order of the 56 birds emitted by more than $10 \%$ of the subjects, together with the frequency for each. Others listed by more than one subject were as follows, with the raw frequency preceding the names: 20 , mallard; 19, goldfinch; 18 , bobolink, grouse, partridge; 17, buzzard, dodo; 15, roadrunner, sandpiper, tern; 14 , bald eagle, cockatoo; 13, warbler, macaw; 12, hen; 11, grackle, kiwi, lovebird, meadowlark, osprey, purple martin; 9, Baltimore oriole, cuckoo, magpie, nuthatch; 8 , flicker, loon, titmouse; 7 , bat; 6 , catbird, egret, tanager; 5 , jay, whooping crane; 4 , bird of paradise, cowbird, martin, redbird, snipe; 3 , emu, bunting, grebe, junco, quetzal, vireo; 2 , crescent, grosbeak, nighthawk, skylark, swallowtail, swift, woodcock. Depending on one's judgment, there were perhaps 30-35 other bird names, each given by one subject.

In Battig and Montague's data, 18 birds were listed by more than $10 \%$ of their subjects. In rank order, these were: robin, sparrow, cardinal, blue jay, eagle, crow, bluebird, canary, parrakeet, hawk, blackbird, wren, oriole, parrot, pigeon, hummingbird, starling, and woodpecker. Comparison with Table 1 shows that these 18 were listed by at least $21 \%$ (rank 35 or higher) of subjects in the present study. Thirteen of Battig and Montague's top 18 appear in the top 18 in Table 1, and 12 of those 13 were emitted by at least $50 \%$ of the Northwestern students.

Comparison of the top $20-30$ birds listed in the two 
Table 1

Rank Order and Frequency of 56 Bird Names Listed by 200 Subjects

\begin{tabular}{lclc}
\hline Response & $\begin{array}{c}\text { Fre- } \\
\text { quency }\end{array}$ & Response & $\begin{array}{c}\text { Fre- } \\
\text { quency }\end{array}$ \\
\hline 1. Robin & 189 & 29. Peacock & 62 \\
2. Eagle & 177 & 30. Pelican & 61 \\
3. Sparrow & 175 & 31. Penguin & 60 \\
4. Cardinal & 148 & 32. Falcon & 58 \\
5. Blue Jay & 145 & 33. Flamingo & 56 \\
6. Hawk & 144 & 34. Finch & 49 \\
7. Crow & 140 & 35. Starling & 42 \\
8. Duck & 129 & 36. Stork & 41 \\
9. Pigeon & 125 & 37. Myna Bird & 40 \\
10. Hummingbird & 122 & 38. Swallow & 39 \\
11. Sea Gull & 121 & 39. Quail & 38 \\
12. Chicken & 113 & 40. Mockingbird & 34 \\
13. Woodpecker & 110 & 41. Raven & 33 \\
14. Parrot & 109 & 42. Condor & 33 \\
15. Owl & 106 & 43. Kingfisher & 32 \\
16. Parrakeet & 100 & 44. Sapsucker & 32 \\
17. Dove & 98 & 45. Lark & 31 \\
18. Canary & 97 & 46. Thrush & 30 \\
19. Ostrich & 95 & 47. Chickadee & 29 \\
20. Pheasant & 94 & 48. Albatross & 28 \\
21. Blackbird & 89 & 49. Crane & 26 \\
22. Vulture & 88 & 50. Red Wing Blackbird 26 \\
23. Goose & 87 & 51. Toucan & 24 \\
24. Turkey & 86 & 52. Rooster & 23 \\
25. Swan & 71 & 53. Nightingale & 22 \\
26. Oriole & 68 & 54. Bobwhite & 22 \\
27. Bluebird & 67 & 55. Heron & 21 \\
28. Wren & 66 & 56. Whippoorwill & 21 \\
\hline
\end{tabular}

studies reveals very few cases of changes of 10 positions or more in rank order; e.g., "duck," ranked 8 in Table 1, 23 in the Battig-Montague study. Another of these ("sea gull") moves from Rank 26 in Battig-Montague to Rank 11 in Table 1, probably because of the popularity among college students of a book and a motion picture about a sea gull near the time the Northwestern data were collected.

One of the purposes of this study has been achieved: Subjects were successfully prodded to give members of a semantic category such that many of the members were emitted with higher frequencies than Battig and Montague obtained. Even though the present study employed less than half as many subjects as did Battig and Montague, 56 bird names were produced by at least $10 \%$ of the Northwestern subjects vs. 18 names achieving
$10 \%$ in Battig-Montague. (This is of course no criticism of Battig and Montague; their procedure was quite different.)

However, the original stimulus for the present study was the rapid decline in frequency after the first very few high-frequency birds in Battig-Montague. A similar sharp decline in frequency from a very few high-frequency names is also present here. In Table 1, only 11 subjects out of 200 did not give "robin." But if one asks how many different birds were given by at least $75 \%$ of the subjects, the answer is just three: robin, eagle, and sparrow. In other words, one-quarter of the subjects did not think of all three of the highest-frequency names. And one has to add only the next four higher-frequency names (cardinal, blue jay, hawk, and crow) to these three to drop to the level where, below that, one-third of the subjects failed to emit at least one of the seven highest-frequency names. This is a striking failure of retrieval by production. Although data on recognition of these bird names are not available, it seems quite likely that the considerable difference between (low) retrieval by production and (high) retrieval by recognition found in another study (Duncan, 1973) would also be found with bird names.

It is perhaps not surprising that low-frequency verbal items are not thought of when the subject is attempting to retrieve by production. For one thing, some low-frequency items are not even recognized (Duncan, 1973), although this can hardly be a major factor in the poor retrieval of low-frequency words. What is surprising is that some relatively high-frequency items are not thought of by many subjects, both in this study and a previous one (Duncan, 1973). Prodded retrieval did result in more of the subjects thinking of more of the names at all frequency levels, but it did not result in almost all of the subjects thinking of all of even the highest frequency names.

\section{REFERENCES}

Battig, William F., \& Montague, William E. Category norms for verbal items in 56 categories: A replication and extension of the Connecticut category norms. Journal of Experimental Psychology Monograph, 1969, 80, No. 3, Part 2, 1-45.

Duncan, Carl P. Storage and retrieval of low-frequency words. Memory and Cognition, 1973, 1, 129-132.

(Received for publication March 17, 1975.) 